\title{
Polar Regions (2020)
}

\author{
Stefan Kirchner*
}

2020 was characterised by the fight against the COVID-19 pandemic, which at the time of writing ${ }^{1}$ has affected more than 100 million people and claimed more than 2 million lives worldwide. In 2020, the SARS-CoV-2 virus reached the remotest parts of the planet, including small communities in the Arctic ${ }^{2}$ and even Antarctica. ${ }^{3}$ In polar regions, the limited health care infrastructure poses a particular challenge when dealing with the pandemic. The ability of regulators to improve the existing infrastructure with the speed the pandemic calls for is rather limited. While some countries have been able to construct hospitals for COVID-19 patients in a very short amount of time, the regulatory approach, especially in the Arctic, has been different. Instead of trying to compensate for structural weaknesses, which are based on geography, history, economy and colonial heritage in administrative settings, many Arctic communities have built on their strengths, such as flexibility, resilience, relative independence and mutual cooperation within communities.

Success stories include Iceland ${ }^{4}$ and Greenland, ${ }^{5}$ which were able to limit the spread of the disease. As Greenland severely limited passenger flights into the country ${ }^{6}$ and brought citizens back to the island, ${ }^{7}$ the importance of the transport of goods by ship has become even more relevant. This, in turn, increased Greenland's dependence on ship transport and emphasised

* Research Professor of Arctic Law, University of Lapland.

1 Early February 2021.

2 Yle, 'One year since Finland's first confirmed Covid-19 case', YLE News (Helsinki, 29 January 2021), <https://yle.fi/uutiset/osasto/news/one_year_since_finlands_first_confirmed_covid-19_ case/11762849> last accessed (as any subsequent URL) on 5 May 2021.

3 Helen Sullivan, 'Covid cases recorded in Antarctica for first time - reports', The Guardian (London, 22 December 2020), <https:/www.theguardian.com/world/2020/dec/22/covid -cases-recorded-in-antarctica-for-first-time $>$.

4 Elizabeth Kolbert, 'How Iceland beat the Coronavirus', The New Yorker (New York, 1 June 2020), <https://www.newyorker.com/magazine/2020/06/o8/how-iceland-beat-the-coronavirus >.

5 Martin Breum, 'A tough strategy of isolation has protected Greenland from coronavirus so far', Arctic Today (Anchorage, 17 April 2020), <https://www.arctictoday.com/a-tough -strategy-of-isolation-has-protected-greenland-from-coronavirus-so-far/>.

6 Visit Greenland, 'Summary of latest changes', Visit Greenland (Nuuk, 21 January 2021), $<$ https://visitgreenland.com/corona-faq/>.

7 Nunatsinni nakorsanneqarfik, 'Ny corona-stategi: Alle udrejste skal hjem', nun.gl (Nuuk, 8 January 2021), <https://nun.gl/emner/borgere/coronavirus_emne/rejsende_i_2O21?sc_lang $=$ da $>$. 
the importance of preventing disasters at sea. Similarly, Faroyar's (the Faroe Islands) response marks a success story in the fight against CoviD-19 because the test and trace system there could be set up, and scaled up, quickly, due to a flexible solution. This response was possible due to the lack of legal constraints which allowed a solution from animal health services to be transferred human health services. The economy and culture of Faroyar, literally meaning the sheep islands, continue to centre on animals. At the beginning of the millennium, Faroyar suffered an outbreak of infectious salmon anaemia virus (ISAV), ${ }^{8}$ a salmon disease, which led to investments in testing capacities for veterinary purposes. ${ }^{9}$ With the arrival of SARS-CoV-2, these technical capacities were quickly repurposed to test for the new coronavirus. ${ }^{10}$ This had already been done in 2009 during an outbreak of H1N1. ${ }^{11}$ Faroyar proves that an effective test and trace system can be crucial for containing the spread of the disease.

The picture, however, is not uniform. While some communities in the Arctic have been successful in dealing with the pandemic, the situation elsewhere continues to be a reason for grave concern. Test-and-trace is an illusion if the entire health care system is at risk of collapsing. This is the case in parts of the Russian Federation ${ }^{12}$ and Sweden..$^{13}$ Often the wellbeing of Arctic communities has been ignored by governments in faraway capital cities, and the pandemic has highlighted pre-existing issues of inequitable access to health services. In the United States and Sweden, attempts to achieve herd immunity by letting the disease run through society as a whole has failed, and both countries have paid a high price in human lives. ${ }^{14}$ This is also the case for com-

8 Sam Morgan, 'Coronavirus secrets of the Faroes', EurActiv (Brussels, 7 April 2020), <https:// www.euractiv.com/section/coronavirus/news/coronavirus-secrets-of-the-faroes/>.

9 Daniel Boffey, 'Veterinary scientist hailed for Faroe Islands' lack of Covid-19 deaths', The Guardian (London, 8 April 2020), <https://www.theguardian.com/world/2020/apr/o8/ vetinary-scientist-hailed-faroe-islands-lack-covid-19-deaths $>$.

$10 \quad$ Ibid.

11 Morgan (n 8).

12 Peter B. Danilov, 'Covid-19 in the Arctic: Dramatic Increase at Russian Construction Site, Introduces Ankle Bracelets to Prevent Spreading', High North News (Bodø, 17 April 2020), <https://www.highnorthnews.com/en/covid-19-arctic-dramatic-increase -russian-construction-site-introduces-ankle-bracelets-prevent $>$.

13 See (also from a comparative Arctic perspective) e.g. Andrey N. Petrov et al., 'Spatiotemporal dynamics of the covid-19 pandemic in the arctic: early data and emerging trends' (2020) 79 International Journal of Circumpolar Health, at <https://doi.org/10.1 o8o/22423982.2020.1835251>.

14 Kelly Bjorklund \& Andrew Ewing, 'The Swedish COVID-19 Response Is a Disaster. It Shouldn't Be a Model for the Rest of the World', Time (New York, 14 October 2020), $<$ https://time.com/5899432/sweden-coronovirus-disaster/>. 
munities in Arctic regions. Apart from closing external borders, a measure which has proven particularly harmful for the indigenous communities who are facing travel restrictions within their homeland, ${ }^{15}$ the regulatory response, especially in Sweden, has been very limited. Border closures can also affect health care workers who live in one country and work in another. This not only concerns health care workers from Finland commuting to Sweden and from Sweden and Denmark to Norway but especially Greenland, which depends on health care workers coming into the island nation. ${ }^{16}$ Exceptions for health care workers had to balance needs and risks, in particular prior to the availability of vaccines.

The pandemic also exposes shortcomings in areas of regulation which usually are not associated with disaster risk reduction, such as the provision of public services. The lack of water supplies in rural Alaska has been identified as a threat after a small community where about one in three residents suffer from COVID-19 was practically cut off from running water in the middle of the winter. ${ }^{17}$ Elsewhere, the availability of affordable and widespread mobile internet services, combined with the possibility of home schooling, ${ }^{18}$ facilitated targeted reactions to outbreaks and allowed local authorities to take swift action without unduly disturbing the provision of public services. The same applies to the availability of public services through electronic means in general. Here countries such as Finland and Estonia (Estonia perceives itself as the northernmost non-Arctic nation and currently is seeking observer status with the Arctic Council) are significantly ahead of many other countries.

By providing legal frameworks that remove the need to obtain public services in person, these technology-oriented nations have contributed to creating regulatory environments capable of coping with disruptions such

15 See Arctic Council, "The Impact of COVID-19 on Saami Communities - Interview with Christina Henriksen, President of the Saami Council', Arctic Council (Tromsø, 16 July 2020), $<$ https://arctic-council.org/en/news/the-impact-of-covid-19-on-saami-communities/>.

16 See also Alexandra Middleton, 'Fly-in Fly-Out Workers in the Arctic: The Need for More Workforce Transparency in the Arctic', The Arctic Institute (Washington D.C., 26 January 2021, <https://www.thearcticinstitute.org/fly-in-fly-out-workers-arctic-need -workforce-transparency-arctic/>.

17 Olivia Ebertz, 'No easy answers after fire destroys Tuluksak's water supply', Alaska Public Media (Anchorage, 25 January 2021), <https://www.alaskapublic.org/2021/01/25/ no-easy-answers-after-fire-destroys-tuluksaks-water-supply/>.

18 Is noteworthy that home schooling continues to be outlawed on some countries, despite the health risks experienced by children in school buildings during the pandemic, see Stefan Kirchner, 'COVID-19 and obligatory school attendance in Germany', in Stefan Kirchner (ed), Governing the Crisis: Law, Human Rights and COVID-19 (Lit Verlag 2021) $115^{-129 .}$ 
as the pandemic or other disasters. The different responses to the pandemic and the prior creation of regulatory frameworks which allow for flexible reactions highlight the need for a holistic approach to disaster risk reduction law. In the health care sector, the "One Health" concept $\mathrm{t}^{19}$ is gaining significant attention also in the Arctic, not only in academic settings, for example, at the virtual Arctic Frontiers conference or in the form of an online conference on One Health in the Arctic at the University of Fairbanks in 2021, but also in the message sent by the Prime Minister of Finland, Sanna Marin, to the General Assembly of the United Nations in $2020^{20}$

Although CoviD-19 was the major issue that dominated public awareness in 2020 , other efforts to use legal tools to reduce the risk of disasters in the polar region deserve to be mentioned as well. The risk of oil spills is significant in Arctic waters, including in the Arctic Ocean, its adjacent waters, and other water bodies such as the Baltic Sea and the Sea of Okhotsk, ${ }^{21}$ which are often not perceived as the Arctic but face similar climatic challenges. Especially along the Northern Sea Route (NSR), maritime traffic continues to increase, particularly from locations like Sabetta in the Russian Federation transport hydrocarbons from Siberia to East Asia, particularly China. In the winter 2020/2021, tanker operations continued into the winter. While climate change significantly alters the Arctic Ocean, ship operations there remain inherently dangerous, and several incidents along the NSR indicate that safety standards have been slipping in recent years. ${ }^{22}$ This increases the likelihood of maritime disasters in a region in which Search-and-Rescue capacities are sparse and where the natural environment is particularly vulnerable, in particular to oil pollution.

Although the pandemic has put the boom in Arctic cruise tourism on pause, for the time being, the long-term interest in tourism in the Arctic is likely to return if public health onboard cruise vessels can be guaranteed. ${ }^{23}$ Already

19 See World Health Organization, 'One Health', wно (Geneva, 21 September 2017), <https:// www.who.int/news-room/q-a-detail/one-health>.

20 Statement by Prime Minister Sanna Marin (Helsinki, 3 December 2020), <https:// estatements.unmeetings.org/estatements/10.0010/20201203/bUaYLBKwgqUv/ PtoRvPoobwdf_en.pdf >.

21 See Stefan Kirchner, 'Protecting the Marine Environment of Non-Polar Ice-Covered Seas', Edilex 2020/5, <https://www.edilex.fi/artikkelit/20492>.

22 See already Malte Humpert, 'Dozens of Vessels Violate Safety Rules on Northern Sea Route', High North News (Bodø, 19 October 2017) <https://www.highnorthnews.com/en/ dozens-vessels-violate-safety-rules-northern-sea-route>.

23 See in detail Stefan Kirchner et al., 'Port State Responses to COVID-19 on Cruise Ships between Human Rights and the Law of the Sea', in Stefan Kirchner (ed), Governing the Crisis: Law, Human Rights and COVID-19 (Lit Verlag 2021) 249-164. 
in late 2019, the Association of Arctic Expedition Cruise Operators (AECO) announced a self-imposed ban on heavy fuel oils in the Arctic. ${ }^{24}$ Such industry self-regulation is not without influence on debates at the international level over the introduction of stricter environmental and safety standards. In polar regions, both in the Arctic and Antarctica, including in the Southern Ocean, the protection of human safety and the natural environment go hand in hand. Reducing the risk of disasters contributes to both these objectives.

2020 was a disastrous year which saw the loss of many human lives. The underlying challenges have not been removed yet. In particular, the pandemic is making fault lines more visible than before: case numbers provide a sad but obvious metric to measure the success or failure of regulatory measures, especially when the situation in two different jurisdictions is otherwise similar, for example, between Sweden and Finland, which share similar geographies, history and legal frameworks, but which have experienced the pandemic in very different ways. ${ }^{25}$ The pandemic is a reminder that regulatory choices have real, life and death impacts on people. International disaster law can be an important tool to guide decision-makers at the national and sub-national levels and for the infusion of specific values, such as the human right to equal access to health care, independent of factors such as nationality, age, wealth or other status, into decision-making processes. As with the case of climate change, which continues to affect polar regions much more than other parts of the world, the effects of the pandemic have turned Arctic nations into examples for the rest of the world - both in terms of successful policies and regulations and in negative ways. While some governments, such as the Trump administration in the United States and the governments in Sweden and Russia have failed to protect their residents, policies enacted elsewhere, for example, in Finland, Iceland and Greenland and also during the Biden presidency in the United States, have been significantly more successful. Policy decisions and regulations have had real impacts on the well-being of residents across the Arctic. All laws have to serve society and humankind. In the case of disaster law, this function is particularly evident. In the polar regions, 2020 was a reminder of the need to put people at the heart of regulatory efforts.

24 Association of Arctic Expedition Cruise Operators, 'Expedition Cruise Industry Charts Courts for Sustainable Arctic Tourism', AEco (Tromsø, 7 November 2019), <https://www .aeco.no/2019/11/expedition-cruise-industry-charts-course-for-sustainable-arctic -tourism/>.

25 See, e.g., Mariam Claeson \& Stefan Hanson, 'COVID-19 and the Swedish enigma' (2021) 397:10271 The Lancet, 259-261, <https://doi.org/10.1016/So140-6736(20)32750-1>. 